EGU2020-13543

https://doi.org/10.5194/egusphere-egu2020-13543

EGU General Assembly 2020

(c) Author(s) 2022. This work is distributed under

the Creative Commons Attribution 4.0 License.

\title{
Contribution of the triple oxygen isotope composition of precipitation to the identification of surface-atmosphere interactions in the sub-humid part of West Africa
}

Christine Vallet-Coulomb ${ }^{1}$, Anne Alexandre ${ }^{1}$, Christophe Peugeot ${ }^{2}$, Abdoukarim Alassane ${ }^{3}$, Vinel Gbewezoun $^{3}$, Martine Couapel ${ }^{1}$, Clément Outrequin ${ }^{1}$, Théodore Ouani ${ }^{4}$, and Simon Afouda ${ }^{4}$

${ }^{1}$ Aix Marseille University, CNRS, IRD, INRA, Coll France, CEREGE, Aix-en-Provence, France (vallet@cerege.fr)

${ }^{2}$ Hydrosciences Montpellier, IRD, CNRS, Univ. Montpellier, Montpellier, France

${ }^{3}$ Laboratoire d'Hydrologie Appliquée, Institut National de I'Eau, Université d'Abomey-Calavi, Bénin

${ }^{4}$ IRD Bénin, 08 BP841 Cotonou, Bénin

This study aims at evaluating the information carried by the ${ }^{17} \mathrm{O}$-excess composition of precipitation in the sub-humid part of West Africa. Located at the southern border of the Sahelian band, the so-called "Sudanian Climatic Zone", characterized by annual precipitation of $1200-1400 \mathrm{~mm}$, plays a crucial role in providing water to large African watersheds such as the Niger river's one, and the Lake Chad catchment. Surface-atmosphere interactions were shown to influence convective processes in the semi-arid Sahelian band, with positive feedbacks between vegetation land cover and rainfall. Less focus has been put on the more humid Sudanian Zone, although surface-atmosphere interactions may have an important influence on the control of rainfall variations, and therefore on water resource availability in these watersheds.

The stable isotope composition of precipitation reflects the combination of different processes associated with phase changes over the atmospheric water cycle, from the initial water vapor formation above the ocean to the raindrop on the ground surface. Classical tracers $\left(\delta^{18} \mathrm{O}, \delta^{2} \mathrm{H}\right.$, and d-excess) are affected by multiple factors (i.e. Rayleigh process, temperature, humidity) changing during these successive steps. In contrast, ${ }^{17} \mathrm{O}$-excess variations mainly records evaporation processes controlled by the humidity conditions that prevail during phase change. There are few available ${ }^{17} \mathrm{O}$-excess studies focusing on precipitation in tropical and sub-tropical areas. They show that the ${ }^{17} \mathrm{O}$-excess in precipitation provides information on 1 ) relative humidity at oceanic moisture sources, and 2) secondary processes, such as raindrop re-evaporation. The contribution of vapor of continental origin, produced either by plant transpiration or soil water evaporation, should additionally affect the ${ }^{17} \mathrm{O}$-excess signature of precipitation, although no data are available so far to evaluate the magnitude of this process.

For the study presented here, we collected precipitation from two sampling stations, both located in Benin and affected by a similar oceanic moisture source in the Gulf of Guinea. The first station (lat. $6^{\circ} 26^{\prime} \mathrm{N}$; long. $2^{\circ} 21^{\prime} \mathrm{E}$ ) is located along the coast and is essentially subject to oceanic influence. The second station (lat. $9^{\circ} 44^{\prime} \mathrm{N}$; long. $1^{\circ} 34^{\prime} \mathrm{E}$ ) is located $400 \mathrm{~km}$ inland and may be additionally 
affected by continental vapor recycling. The stable isotope composition of rainfall samples $\left(\delta^{2} \mathrm{H}\right.$, $\delta^{18} \mathrm{O}$ and $\delta^{17} \mathrm{O}$ ) are measured on a WS-CRDS Picarro L2140-i, using three replicates per sample. Comparison between those two records allow to investigate how humidity at the oceanic source, raindrop re-evaporation and continental vapor contribute to the ${ }^{17} \mathrm{O}$-excess signature of precipitation. 